\title{
Genetic diversity in Fagus crenata (Japanese beech): influence of the distributional shift during the late-Quaternary
}

\author{
NOBUHIRO TOMARU*, TOMOMI MITSUTSUJI, MAKOTO TAKAHASHI†, YOSHIHIKO \\ TSUMURA $\ddagger$ KOHJI UCHIDA \& KIHACHIRO OHBA \\ Institute of Agriculture and Forestry, University of Tsukuba, Tsukuba, Ibaraki 305, †Tohoku Breeding Office, National \\ Forest Tree Breeding Center, Takizawa, Iwate 020-01 and $\ddagger$ Bio-resources Technology Division, Forestry and Forest \\ Products Research Institute, Kukizaki, Ibaraki 305, Japan.
}

\begin{abstract}
Genetic diversity at 11 loci encoding nine enzymes was studied in 23 populations of Japanese beech Fagus crenata Blume distributed throughout the range of the species. Levels of genetic diversity were high for both within species (expected mean heterozygosity: 0.194) and within populations (expected mean heterozygosity: 0.187), whereas the level of genetic diversity among populations was low $\left(G_{\mathrm{ST}}=0.038\right)$, as observed in various long-lived, woody plants. Despite the low differentiation among populations, geographical patterning of the variation was observed. Populations in south-western Japan tended to have greater within-population variation and to be more highly differentiated when compared with those in north-eastern Japan. In addition, allele frequencies observed at eight loci were significantly related to latitudinal and/or longitudinal gradients and showed clinal variation across the range of the species. Principal components analysis revealed that the populations tended to cluster according to their geographical locations. The nonrandom patterns of variation were probably shaped by relatively recent historical events such as late-Quaternary migration and founding events.
\end{abstract}

Keywords: allozymes, Fagus crenata, founding events, genetic variation, population differentiation, population expansion.

\section{Introduction}

Many allozyme studies examining genetic diversity of plant species have shown that various species maintain high levels of genetic diversity within natural populations. Among plant species, longlived, woody species maintain higher levels of variation both within species and within populations and, further, show less genetic differentiation among populations compared with other plant species. In general, this tendency is related with longevity, large contiguous populations, allogamy and widely dispersed pollen and seed, as these life history and ecological traits tend to maintain high intrapopulation variation and prevent interpopulation differentiation (Brown, 1979; Hamrick et al., 1979;

\footnotetext{
*Correspondence and present address: Bio-resources Technology Division, Forestry and Forest Products Research Institute, Kukizaki, Ibaraki 305, Japan. E-mail: ntomaru@ffpri.affrc.go.jp
}

Gottlieb, 1981; Hamrick \& Godt, 1989; Hamrick et al., 1992). Certainly, several life history and ecological traits of species are significantly related to the level and distribution of genetic diversity in plant species. However, these traits only account for less than one-half of the heterogeneity observed in genetic diversity among species (Hamrick \& Godt, 1989; Hamrick et al., 1992). Hamrick et al. (1992) noted that the remaining heterogeneity was probably explained by the evolutionary history of each species.

The Japanese Archipelago extends lengthwise from north-east to south-west with various mountain ranges running parallel to it. In general, past major climatic changes forced temperate plant species to migrate along either the Pacific Ocean side, the Japan Sea side or along the mountain slopes; i.e. during glacial periods they migrated either southwards or to lower altitudes into refugia, and during interglacial periods they expanded either northwards 
or to higher altitudes (Tsukada, 1980). Therefore, knowledge of the evolutionary history of temperate plant species, including shifts in distribution, fragmentation and population isolation, especially after the last glacial maximum, would help interpret the current genetic diversity.

Japanese beech forests, common in the cool temperate zone, are widely distributed from the Kuromatsunai lowland in Hokkaido to Mt. Takakuma in Kyushu (Horikawa, 1972; The Environment Agency, 1988; Fig. 1). The present centre of the distribution is in north-eastern Honshu on the Japan Sea side where beech forests remain in relatively large areas despite being fragmented in montane areas (mostly 200-1400 m elevation) because of post-World War II exploitation. On the other hand, the distribution from central Honshu on the Pacific Ocean side to south-western Japan is scattered and isolated in small montane areas mostly higher than $1000 \mathrm{~m}$ in elevation.

Relatively extensive data of radiocarbon-dated pollen analyses have been reported for Fagus spp. (mainly $F$. crenata, but including $F$. japonica) and Tsukada $(1982 \mathrm{a}, \mathrm{b})$ reviewed them for an understanding of the late-Quaternary vegetation history. Takahashi et al. (1994) analysed allozyme variation in $F$. crenata populations in north-eastern Japan. However, there is no comprehensive allozyme study using natural populations sampled across the entire natural range of the species. In this report, we illustrate the genetic variation and population differentiation of $F$. crenata across its entire distribution, and elucidate the role of the late-Quaternary distributional shift in shaping the geographical variation revealed by allozyme markers.

\section{Materials and methods}

\section{Plant materials}

In this study we sampled 23 populations covering the naturally distributed areas of $F$. crenata (Fig. 1 and Table 3). To assess genetic diversity in the entire species distribution, the populations used in this study also included the 11 populations which were used by Takahashi et al. (1994) to estimate allozyme diversity of $F$. crenata forests in north-eastern Japan.

Winter buds were collected from 624 trees in the remaining 12 south-western populations during October and March; 20-30 winter buds were collected from each individual. To avoid sampling half-sib individuals sampled trees were separated by approximately $50 \mathrm{~m}$ and no attention was paid to the age or size of trees. Buds were stored at $-80{ }^{\circ} \mathrm{C}$

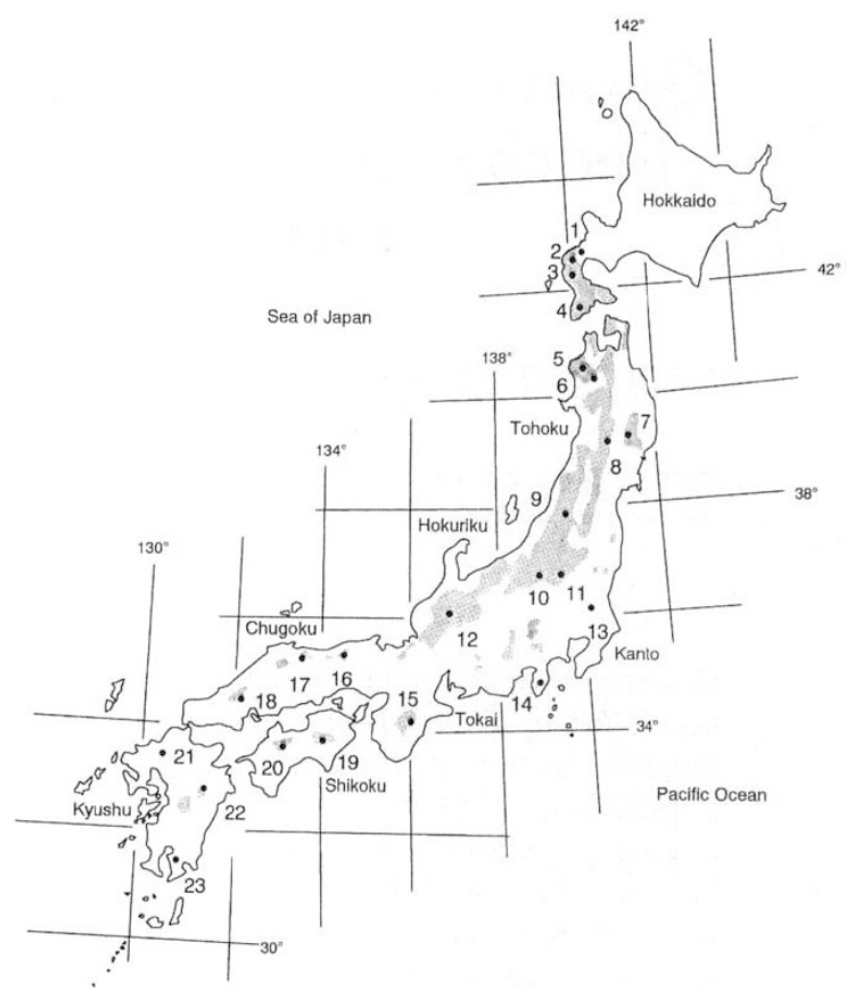

Fig. 1 Present distribution of Fagus crenata forests. Dots identify sample population locations; numbers correspond to population numbers in Table 3. prior to isozyme analysis.

\section{Enzyme electrophoresis}

Enzyme extraction, electrophoresis and staining methods were similar to those described by Tsumura \& Ohba (1993). Fifty milligrams of winter bud tissue was ground to a fine powder with a mortar and pestle using liquid nitrogen. Immediately after grinding, $50 \mathrm{mg}$ of polyvinylpolypyrrolidone and $1 \mathrm{~mL}$ of extraction buffer ( $93 \mathrm{~mm}$ Tris- $\mathrm{HCl}(\mathrm{pH} 7.5), 23.4$ per cent glycerol, 0.6 per cent Tween 80, $12.0 \mathrm{~mm}$ DTT, $2.8 \mathrm{~mm}$ EDTA, $0.6 \mathrm{~mm}$ NAD, $0.5 \mathrm{~mm}$ NADP, 0.5 per cent 2-mercaptoethanol, 0.08 per cent BSA) were added. Individual homogenates were centrifuged at $30000 \mathrm{~g}$ and $0^{\circ} \mathrm{C}$ for $40 \mathrm{~min}$. Ten microlitres of supernatant per lane was used in polyacrylamide vertical slab gel electrophoresis (Davis, 1964; Ornstein, 1964) for $150 \mathrm{~min}$ at $4^{\circ} \mathrm{C}$ and $12.3 \mathrm{~mA} \mathrm{~cm}{ }^{-2}$. A running gel ( 7.5 per cent) and a spacer gel ( 3.75 per cent) were used. All samples were analysed for nine enzyme systems and scored for a total of 11 loci as follows: alcohol dehydrogenase (ADH, EC 1.1.1.1), Adh-3; malate dehydrogenase (MDH, EC 1.1.1.37), $M d h-2$ and $M d h-3$; 6-phosphogluconate dehydrogenase (6PGD, EC 1.1.1.44), 6Pg-2; diaphorase (DIA, EC 1.8.1.4), Dia; 
glutamic oxaloacetic transaminase (GOT, EC 2.6.1.1), Got; amylase (AMY, EC 3.2.1), Amy-3; alanine aminopeptidase (AAP, EC 3.4.11.1), Aap-1 and Aap-2; fumarase (FM, EC 4.2.1.2), Fm; and phosphoglucoisomerase (PGI, EC 5.3.1.9), Pgi-1. Genetic control of the expression of the various isozymes were inferred by Takahashi et al. (1994).

\section{Statistical analysis}

To estimate within-population variation, five parameters were estimated from allele frequencies: the proportion of polymorphic loci $\left(P_{1}\right)$ at the 95 per cent level; the average number of alleles per locus $\left(N_{\mathrm{a}}\right)$; the effective number of alleles per locus $\left(N_{\mathrm{e}}\right.$; Kimura \& Crow, 1964); the expected and observed average heterozygosities $\left(H_{\mathrm{e}}\right.$ and $\left.H_{\mathrm{o}}\right)$, where $H_{\mathrm{e}}$ was an unbiased estimate (Nei, 1978; Nei \& Roychoudhury, 1974). The fixation index ( $\left.F_{\text {IS }}\right)$ for polymorphic loci in each population and its averages across both populations and loci were determined (Wright, 1965; Nei, 1977). Deviations from Hardy-Weinberg equilibra were tested using $\chi^{2}$ (Li \& Horvitz, 1953).

Gene diversity statistics (Nei, 1973; Nei \& Chesser, 1983) were estimated as follows: $H_{\mathrm{T}}=H_{\mathrm{S}}+D_{\mathrm{ST}}$ and $G_{\mathrm{ST}}=D_{\mathrm{ST}} / H_{\mathrm{T}}$, where $H_{\mathrm{T}}$ is the gene diversity in the total population, and $H_{\mathrm{S}}$ and $D_{\mathrm{ST}}$ are the average gene diversities within and between populations, respectively. $G_{\mathrm{ST}}$ is the relative extent of gene differentiation among populations. As suggested by $\mathrm{Nei}$ (1973), statistical averages were obtained over all loci to clarify a general mode of differentiation among populations. An average was also obtained for polymorphic loci only to compare with those of other species mentioned by Hamrick \& Godt (1989) and Hamrick et al. (1992). The statistical significance of the deviation of $G_{\text {ST }}$ from zero was tested using $\chi^{2}$ (Workman \& Niswander, 1970).

An additional measure of population differentiation was $D_{j}$ (Gregorius \& Roberds, 1986), defined as the genetic distance between the $j$ th population and the remaining populations as follows:

$D_{j}=\frac{1}{2} \sum_{i}\left|p_{i}(j)-\bar{p}_{i}(j)\right|$,

where $p_{i}(j)$ and $\bar{p}_{i}(j)$ are the frequencies of the $i$ th allele in the $j$ th population and in the remaining populations, respectively. This measure indicates the proportion of alleles by which one population differs from all the other populations. If the $j$ th population is identical to, or completely different from, the remaining populations, the values of $D_{j}$ are 1 or 0 , respectively.

(C) The Genetical Society of Great Britain, Heredity, 78, 241-251.
Nei's unbiased genetic distances were calculated for all population pairs (Nei, 1972; Nei \& Roychoudhury, 1974). To estimate the amount of gene flow among populations, the number of migrants exchanged per generation, $\mathrm{Nm}$, was calculated indirectly from $G_{\mathrm{ST}}$ values at each locus and from the average values over all loci by applying Wright's (1931) infinite island formula: $\mathrm{Nm}=$ $\left(1-G_{\mathrm{ST}}\right) / 4 G_{\mathrm{ST}}$, where $N$ is the effective population size and $m$ is the proportion of migrants exchanged per generation.

Significance tests in parametric linear regression $(t$-test) and in nonparametric regression (ordering test; Quenouille, 1952) were performed for the regression coefficients of the parameters (allele frequencies, $P_{1}, N_{\mathrm{e}}, H_{\mathrm{e}}$ and $D_{j}$ ) against latitude and longitude of the 23 populations to identify relationships between genetic variation in populations and the latitudinal or longitudinal gradients. Furthermore, genetic relationships among populations were explored by principal components analysis based on a variance-covariance matrix of angular-transformed frequencies for all alleles in the 23 populations (SAS Institute, 1985).

\section{Results}

Number of alleles at each locus and patterns of allele distribution

A total of 44 alleles, at 11 loci, across 23 populations were detected. The number of alleles detected at each locus ranged from two at $M d h-2$ to seven at $P g i-1$, the average being four. The allele frequencies for each population appeared relatively homogeneous; the most common alleles at each locus were identical over all populations. However, the differences among populations emerged as different frequencies of shared alleles and the presence and absence of rare alleles. Despite most of the frequencies fluctuating greatly along the geographical transect, 19 alleles (43 per cent) were found to be significantly related to latitudinal and/or longitudinal gradients throughout the species range (Table 1). Many rare alleles were detected in widely scattered localities. For the Pgi-1 locus, however, allele $f$ was detected only in south-western populations located in the Kanto, Tokai, Chugoku, Shikoku and Kyushu districts, and alleles $e$ and $g$ in more south-western populations located in the Chugoku, Shikoku and Kyushu districts.

\section{Agreement with Hardy-Weinberg expectations}

For estimating $F_{\text {IS }}, 149$ genotype distributions for each polymorphic locus in each population were 
Table 1 Significance tests for regression coefficients of allele frequencies against latitude and longitude for 23 populations of Fagus crenata

\begin{tabular}{|c|c|c|c|c|c|c|c|c|}
\hline \multirow[b]{3}{*}{ Locus } & \multirow[b]{3}{*}{ Allele } & \multirow{3}{*}{$\begin{array}{l}\text { Range of } \\
\text { the frequency }\end{array}$} & \multicolumn{3}{|c|}{ Latitude } & \multicolumn{3}{|c|}{ Longitude } \\
\hline & & & \multicolumn{2}{|c|}{$\begin{array}{c}\text { Parametric } \\
\text { test } \dagger\end{array}$} & \multirow{2}{*}{$\frac{\begin{array}{c}\text { Nonparametric } \\
\text { test } \ddagger\end{array}}{P}$} & \multicolumn{2}{|c|}{$\begin{array}{c}\text { Parametric } \\
\text { test } \dagger\end{array}$} & \multirow{2}{*}{$\frac{\begin{array}{c}\text { Nonparametric } \\
\text { test } \ddagger\end{array}}{P}$} \\
\hline & & & $r^{2}$ & $P$ & & $r^{2}$ & $P$ & \\
\hline Adh-3 & $a$ & $0.793-0.990$ & 0.282 & $<0.01$ & $<0.01$ & 0.226 & $<0.05$ & $<0.05$ \\
\hline \multirow[t]{3}{*}{$M d h-3$} & $a$ & $0.000-0.214$ & 0.633 & $<0.001$ & $<0.001$ & 0.689 & $<0.001$ & $<0.001$ \\
\hline & $b$ & $0.625-0.915$ & 0.292 & $<0.01$ & $<0.005$ & 0.537 & $<0.001$ & $<0.01$ \\
\hline & $c$ & $0.027-0.235$ & 0.202 & $<0.05$ & 0.057 & 0.084 & 0.180 & 0.090 \\
\hline \multirow[t]{2}{*}{ Dia } & $a$ & $0.000-0.128$ & 0.258 & $<0.05$ & $<0.05$ & 0.289 & $<0.01$ & $<0.01$ \\
\hline & $b$ & $0.856-1.000$ & 0.333 & $<0.005$ & $<0.05$ & 0.364 & $<0.005$ & $<0.005$ \\
\hline Got & $a$ & $0.000-0.106$ & 0.229 & $<0.05$ & $<0.01$ & 0.424 & $<0.001$ & $<0.005$ \\
\hline \multirow[t]{2}{*}{ Amy-3 } & $b$ & $0.110-0.500$ & 0.779 & $<0.001$ & $<0.001$ & 0.546 & $<0.001$ & $<0.005$ \\
\hline & $e$ & $0.440-0.860$ & 0.706 & $<0.001$ & $<0.001$ & 0.557 & $<0.001$ & $<0.001$ \\
\hline \multirow[t]{2}{*}{ Aap-1 } & $b$ & $0.830-1.000$ & 0.161 & 0.058 & $<0.05$ & 0.219 & $<0.05$ & $<0.05$ \\
\hline & $c$ & $0.000-0.152$ & 0.104 & 0.133 & 0.131 & 0.201 & $<0.05$ & 0.106 \\
\hline \multirow[t]{2}{*}{ Fm } & $a$ & $0.130-0.590$ & 0.171 & 0.050 & 0.107 & 0.309 & $<0.01$ & $<0.05$ \\
\hline & $b$ & $0.410-0.870$ & 0.171 & 0.050 & 0.107 & 0.309 & $<0.01$ & $<0.05$ \\
\hline \multirow[t]{6}{*}{ Pgi-1 } & $b$ & $0.000-0.117$ & 0.394 & $<0.005$ & $<0.005$ & 0.608 & $<0.001$ & $<0.005$ \\
\hline & $c$ & $0.680-0.968$ & 0.498 & $<0.001$ & $<0.005$ & 0.460 & $<0.001$ & $<0.05$ \\
\hline & $d$ & $0.000-0.075$ & 0.510 & $<0.001$ & $<0.001$ & 0.564 & $<0.001$ & $<0.001$ \\
\hline & $e$ & $0.000-0.080$ & 0.367 & $<0.005$ & $<0.001$ & 0.508 & $<0.001$ & $<0.001$ \\
\hline & $f$ & $0.000-0.170$ & 0.215 & $<0.05$ & $<0.005$ & 0.060 & 0.262 & $<0.01$ \\
\hline & $g$ & $0.000-0.066$ & 0.304 & $<0.01$ & $<0.05$ & 0.419 & $<0.001$ & $<0.05$ \\
\hline
\end{tabular}

$\dagger t$-test.

¥The ordering test (Quenouille, 1952).

used and compared with the expected genotype distributions under Hardy-Weinberg equilibrium (Table 2). For loci Adh-3, Got and Aap-2, $F_{1 \mathrm{~s}}$ was estimated in 18, 11 and four populations, respectively, of which 16 ( 89 per cent), five (45 per cent) and three (75 per cent) populations, respectively, had significantly positive values. At least one null allele was detected at the three loci each by no staining intensity on the same gel. In such cases, as heterozygotes with a null allele cannot be distinguished electrophoretically from homozygotes, $F_{1 \mathrm{I}}$ values will be biased towards a positive deviation. Thus, deviation at these loci should be attributed to the null allele's occurrence, rather than to other evolutionary causes.

For loci $6 P g-2$ and $\mathrm{Fm}$, one of two populations and five of 23 populations, respectively, do not meet the expectation and they contributed significantly to mean positive $F_{1 s}$ values at both loci, indicating a significant excess of homozygotes compared with average expectations. Mean values at the remaining polymorphic loci Mdh-3, Dia, Amy-3, Aap-1 and Pgi-1
Table 2 Fixation indices $\left(F_{\text {IS }}\right)$ at polymorphic loci in 23 populations of Fagus crenata $\dagger$

No. of populations

\begin{tabular}{lccc}
\hline & \multicolumn{2}{c}{ No. of populations } \\
\cline { 2 - 3 } Locus & Estimated $F_{\text {IS }} \neq$ & $\begin{array}{c}\text { Deviated from } \\
\text { the expectations* }\end{array}$ & Mean $F_{\text {IS }}$ \\
\hline Adh -3 & 18 & 16 & $0.395^{* * *}$ \\
Mdh-2 & 0 & 0 & - \\
Mdh-3 & 23 & 3 & $0.003 \mathrm{NS}$ \\
6Pg-2 & 2 & 1 & $0.179^{*}$ \\
Dia & 12 & 1 & $0.049 \mathrm{NS}$ \\
Got & 11 & 5 & $0.353^{* * *}$ \\
Amy-3 & 23 & 1 & $0.001 \mathrm{NS}$ \\
Aap-1 & 16 & 1 & $0.045 \mathrm{NS}$ \\
Aap-2 & 4 & 3 & $0.411^{* * *}$ \\
Fm & 23 & 5 & $0.127^{* * *}$ \\
Pgi-1 & 17 & 0 & $-0.064 \mathrm{NS}$ \\
\hline
\end{tabular}

$\dagger$ Levels of significance: NS, not significant; ${ }^{*} P<0.05$; $* * * P<0.001$.

$\ddagger F_{\text {Is }}$ for each locus of each population was estimated in the populations in which the loci were polymorphic. 
Table 3 Proportions of polymorphic loci $\left(P_{i} ; 95\right.$ per cent criterion), average numbers of alleles per locus $\left(N_{\mathrm{a}}\right)$, effective numbers of alleles per locus $\left(N_{\mathrm{e}}\right)$, average observed heterozygosities $\left(H_{\mathrm{o}}\right)$ and fixation indices $\left(F_{\mathrm{IS}}\right)$ in 23 populations of Fagus crenata $\dagger$

\begin{tabular}{|c|c|c|c|c|c|c|c|c|}
\hline Population & Locality & Altitude (m) & $N \ddagger$ & $P_{1}$ & $N_{\mathrm{a}}$ & $N_{\mathrm{e}}$ & $H_{\mathrm{o}}$ & $F_{\text {Is }}$ \\
\hline 1 & Kuromatsunai, Hokkaido & $40-90$ & 80 & 54.5 & $2.18(0.23)$ & $1.28(0.10)$ & $0.157(0.049)$ & $0.166^{*}$ \\
\hline 2 & Mts. Kariba, Hokkaido & $550-790$ & 91 & 63.6 & $2.18(0.30)$ & $1.32(0.10)$ & $0.163(0.052)$ & 0.059 \\
\hline 3 & Mt. Urappudake, Hokkaido & $190-350$ & 62 & 54.5 & $2.55(0.28)$ & $1.30(0.12)$ & $0.191(0.075)$ & -0.207 \\
\hline 4 & Mt. Sengendake, Hokkaido & $50-650$ & 111 & 54.5 & $2.36(0.31)$ & $1.25(0.10)$ & $0.141(0.052)$ & 0.049 \\
\hline 5 & Mts. Shirakami, Aomori & $400-750$ & 143 & 45.5 & $2.55(0.31)$ & $1.22(0.09)$ & $0.132(0.041)$ & 0.101 \\
\hline 6 & Mts. Shirakami, Akita & $550-860$ & 119 & 63.6 & $3.09(0.44)$ & $1.26(0.10)$ & $0.143(0.048)$ & 0.096 \\
\hline 7 & Mt. Hayachine, Iwate & $660-1250$ & 60 & 63.6 & $2.36(0.34)$ & $1.33(0.13)$ & $0.188(0.067)$ & -0.100 \\
\hline 8 & Mt. Mahirudake, Iwate & $460-910$ & 105 & 54.5 & $2.73(0.43)$ & $1.27(0.11)$ & $0.161(0.055)$ & -0.010 \\
\hline 9 & Mts. Iide, Yamagata & $400-640$ & 63 & 54.5 & $2.91(0.37)$ & $1.30(0.11)$ & $0.191(0.061)$ & -0.094 \\
\hline 10 & Mt. Naeba, Niigata & $780-1140$ & 70 & 54.5 & $2.82(0.30)$ & $1.29(0.10)$ & $0.183(0.058)$ & -0.039 \\
\hline 11 & Oze bog, Gumma & $1200-1730$ & 112 & 63.6 & $3.18(0.40)$ & $1.30(0.09)$ & $0.163(0.048)$ & 0.090 \\
\hline 12 & Mt. Hakusan, Gifu & $800-1100$ & 51 & 72.7 & $2.64(0.34)$ & $1.27(0.11)$ & $0.171(0.053)$ & $0.126^{*}$ \\
\hline 13 & Mt. Tsukuba, Ibaraki & $800-876$ & 48 & 54.5 & $2.36(0.30)$ & $1.24(0.07)$ & $0.135(0.043)$ & 0.034 \\
\hline 14 & Mt. Amagi, Shizuoka & $1000-1100$ & 53 & 45.5 & $2.82(0.41)$ & $1.23(0.07)$ & $0.150(0.041)$ & -0.033 \\
\hline 15 & Mt. Ohdaigahara, Nara & $1300-1600$ & 57 & 45.5 & $2.55(0.37)$ & $1.20(0.07)$ & $0.130(0.045)$ & 0.085 \\
\hline 16 & Mt. Ohginosen, Tottori & $1100-1300$ & 50 & 72.7 & $2.55(0.25)$ & $1.35(0.09)$ & $0.194(0.052)$ & 0.011 \\
\hline 17 & Mt. Daisen, Tottori & $900-1300$ & 59 & 45.5 & $2.55(0.25)$ & $1.24(0.08)$ & $0.145(0.043)$ & 0.098 \\
\hline 18 & Mt. Jyakuchi, Yamaguchi & $1100-1300$ & 50 & 63.6 & $3.00(0.36)$ & $1.31(0.08)$ & $0.189(0.043)$ & 0.124 \\
\hline 19 & Mt. Tsurugi, Tokushima & $600-700$ & 50 & 72.7 & $2.73(0.41)$ & $1.30(0.10)$ & $0.183(0.058)$ & -0.017 \\
\hline 20 & Mt. Ishizuchi, Ehime & $1600-1900$ & 52 & 63.6 & $2.73(0.30)$ & $1.32(0.10)$ & $0.176(0.051)$ & $0.193^{* *}$ \\
\hline 21 & Mt. Seburi, Fukuoka and Saga & $900-1055$ & 49 & 72.7 & $3.00(0.43)$ & $1.41(0.12)$ & $0.225(0.061)$ & 0.028 \\
\hline 22 & Mt. Sobo, Miyazaki & $1500-1757$ & 55 & 54.5 & $2.64(0.43)$ & $1.33(0.11)$ & $0.199(0.057)$ & 0.003 \\
\hline 23 & Mt. Takakuma, Kagoshima & $1000-1230$ & 50 & 63.6 & $2.64(0.39)$ & $1.35(0.12)$ & $0.195(0.063)$ & 0.011 \\
\hline Mean & & & 71.3 & 58.9 & $2.66(0.35)$ & $1.29(0.10)$ & $0.170(0.053)$ & 0.034 \\
\hline
\end{tabular}

$\dagger$ Standard errors are in parentheses.

$\ddagger$ Sample size.

$\S F_{\text {IS }}$ values of each population were estimated from average $F_{\text {IS }}$ values at loci apart from $A d h-3$, Got and Aap-2; levels of significance: ${ }^{*} P<0.05 ;{ }^{* *} P<0.01$.

were not significant. The $F_{\text {Is }}$ values were also averaged across loci in each population excluding those at $A d h-3$, Got and Aap-2 because these loci had null alleles (Table 3). Population numbers 1, 12 and 20 had significantly positive values. However, neither the values in the remaining 20 populations nor the average value across all 23 populations $(0.034)$ were significant. Therefore, as a whole and with only slight exceptions, these results suggest that $F$. crenata populations obey the Hardy-Weinberg Law.

\section{Genetic variation within populations}

Parameters of genetic variability within populations for the 23 populations are presented in Table 3 and Fig. 2. Averaged across all populations, the proportion of polymorphic loci $\left(P_{1}\right)$ was 58.9 . The average and effective numbers of alleles per locus $\left(N_{\mathrm{a}}\right.$ and $N_{\mathrm{e}}$ ) were 2.66 and 1.29 , respectively. The average observed heterozygosity $\left(H_{0}\right)$ was 0.170 . For average expected heterozygosity $\left(H_{\mathrm{e}}\right)$, the average value and standard deviation across all populations was $0.187 \pm 0.025$. Figure 2 shows that the $H_{\mathrm{e}}$ (black dots) of populations tended to decrease with increasing latitude and longitude. In the regression tests, a significant relationship was found between $H_{\mathrm{e}}$ and longitude in the parametric test $\left(r^{2}=0.324\right.$, $P<0.005)$ and in the nonparametric test $(P<0.05)$. No significant relationship between $H_{\mathrm{e}}$ and latitude was observed, although if the $H_{\mathrm{e}}$ value $(0.140)$ of population number 15 (the lowest value among populations) was excluded from the test, a significant relationship emerged in the parametric test $\left(r^{2}=0.240, P<0.05\right)$ and in the nonparametric test $(P<0.05) . N_{\mathrm{e}}$ was also significantly related to longitudinal gradient in the parametric test $\left(r^{2}=0.272\right.$, $P<0.05)$ and in the nonparametric test $(P<0.05)$. Therefore, populations in south-western Japan tend to show greater within-population variation than those in north-eastern Japan. No such relationships 

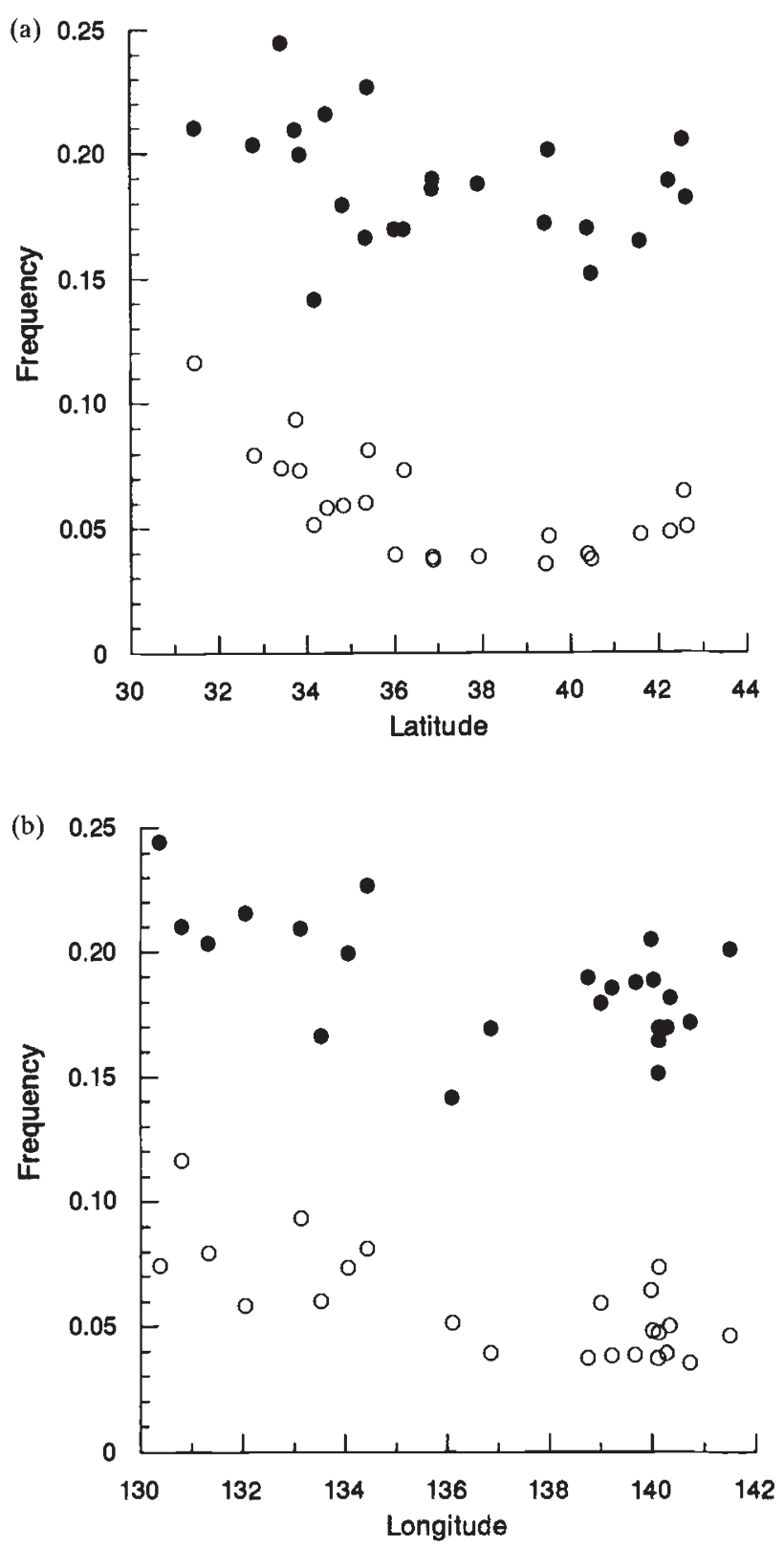

Fig. 2 Relationships of average expected heterozygosities $\left(H_{\mathrm{e}}\right.$; black dots) and the proportions of alleles by which one population differs from all the other populations $\left(D_{j}\right.$; white dots) against latitude (a) and longitude (b) for 23 populations of Fagus crenata.

were found for combinations of $P_{1}$ and either latitude or longitude, or for $N_{\mathrm{e}}$ and latitude.

\section{Population differentiation}

Averaging values of $D_{j}$ across all populations showed that the proportion of alleles by which a population differed from all the other populations was $0.057 \pm 0.021(\mathrm{SD})$. When $D_{j}$ values in each population were plotted against latitude and longitude (Fig. 2, white dots) $D_{j}$ tended to decrease with increasing latitude in the parametric test $\left(r^{2}=0.403, P<0.005\right)$ and in the nonparametric test $(P<0.005)$. Furthermore, $D_{j}$ was also significantly related to latitudinal gradient in the parametric test $\left(r^{2}=0.529, P<0.001\right)$ and in the nonparametric test $(P<0.005)$.

All $G_{\mathrm{ST}}$ values for each locus were low (Table 4). However, apart from $6 P g-2$, the values of $G_{\mathrm{ST}}$ were statistically significant $(P<0.01$ or $<0.001)$, indicating that significant heterogeneities of allele frequencies existed among populations at those loci. Both the mean $G_{\mathrm{ST}}$ values for all loci and only for polymorphic loci excluding $M d h-2$ were 0.038 . Thus, only 4 per cent of the total variation resulted from differences between populations. The mean value of $G_{\mathrm{ST}}$ at polymorphic loci was also statistically significant $(P<0.001$; Table 4). The number of migrants exchanged per generation among the 23 populations, $\mathrm{Nm}$, ranged from 3.8 to 49.8 (mean 6.3; Table 4). As predicted by the small $G_{\mathrm{ST}}$ values, unbiased genetic distances between populations were small, ranging from 0.000 to 0.036 (mean 0.009 ).

\section{Patterns of population relationship}

Genetic relationships among populations were visualized by plotting the populations' first two principal components in two-dimensional space (Fig. 3). Strong regressions were revealed for population position on the first principal component against both latitude and longitude $\left(r^{2}=0.790, P<0.001\right.$; $\left.r^{2}=0.823, P<0.001\right)$. In a further multiple regression analysis with the first principal component against latitude and longitude, 88.2 per cent of the variance of the first principal component was explained by latitude and longitude, i.e. by geographical locations of populations.

\section{Discussion}

\section{Level of within-population and within-species genetic variation and extent of population differentiation}

As summarized by Hamrick \& Godt (1989) and Hamrick et al. (1992), F. crenata was found to maintain high genetic diversity comparable to other woody plants. When compared with other long-lived woody plants, the level of genetic variation within $F$. crenata populations was greater. The average values of parameters describing within-population variation 
Table 4 Gene diversity statistics and the number of migrants exchanged per generation $(\mathrm{Nm})$ for 11 loci in Fagus crenata $\dagger$

\begin{tabular}{lccccr}
\hline Locus & $H_{\mathrm{T}}$ & $H_{\mathrm{S}}$ & $D_{\mathrm{ST}}$ & $G_{\mathrm{ST}} \neq$ & $\mathrm{Nm}$ \\
\hline Adh-3 & 0.195 & 0.191 & 0.004 & $0.018^{* * *}$ & 13.6 \\
Mdh-2 & 0.002 & 0.002 & 0.000 & 0.019 & 12.9 \\
Mdh-3 & 0.353 & 0.341 & 0.012 & $0.034^{* * *}$ & 7.1 \\
6Pg-2 & 0.033 & 0.032 & 0.000 & $0.005 \mathrm{NS}$ & 49.8 \\
Dia & 0.114 & 0.113 & 0.001 & $0.012^{* * *}$ & 20.6 \\
Got & 0.118 & 0.115 & 0.004 & $0.030^{* * *}$ & 8.1 \\
Amy-3 & 0.478 & 0.458 & 0.020 & $0.042^{* * *}$ & 5.7 \\
Aap-1 & 0.135 & 0.133 & 0.002 & $0.013^{* *}$ & 19.0 \\
Aap-2 & 0.054 & 0.051 & 0.003 & $0.051^{* * *}$ & 4.7 \\
Fm & 0.435 & 0.408 & 0.027 & $0.061^{* * *}$ & 3.8 \\
Pgi-1 & 0.217 & 0.208 & 0.009 & $0.043^{* * *}$ & 5.6 \\
Mean & & & & & \\
Polymorphic loci & 0.213 & 0.205 & 0.008 & $0.038^{* * *}$ & \\
& $(0.050) \S$ & $(0.047)$ & $(0.003)$ & $(0.006)$ & \\
All loci & 0.194 & 0.187 & 0.007 & 0.038 & 6.3 \\
& $(0.049)$ & $(0.046)$ & $(0.003)$ & $(0.006)$ & \\
\hline
\end{tabular}

$\dagger$ Gene diversity statistics: $H_{\mathrm{T}}$ is the gene diversity in the total populations; $H_{\mathrm{S}}$ and $D_{\mathrm{ST}}$ are the average gene diversities within and between populations, respectively; $G_{\mathrm{ST}}$ is the relative extent of gene differentiation among populations.

$\ddagger$ Levels of significance: NS, not significant; ${ }^{* *} P<0.01 ;{ }^{* *} P<0.001$. The test for $M d h-2$ could not be carried out because it was monomorphic.

$\S$ Standard errors are in parentheses.

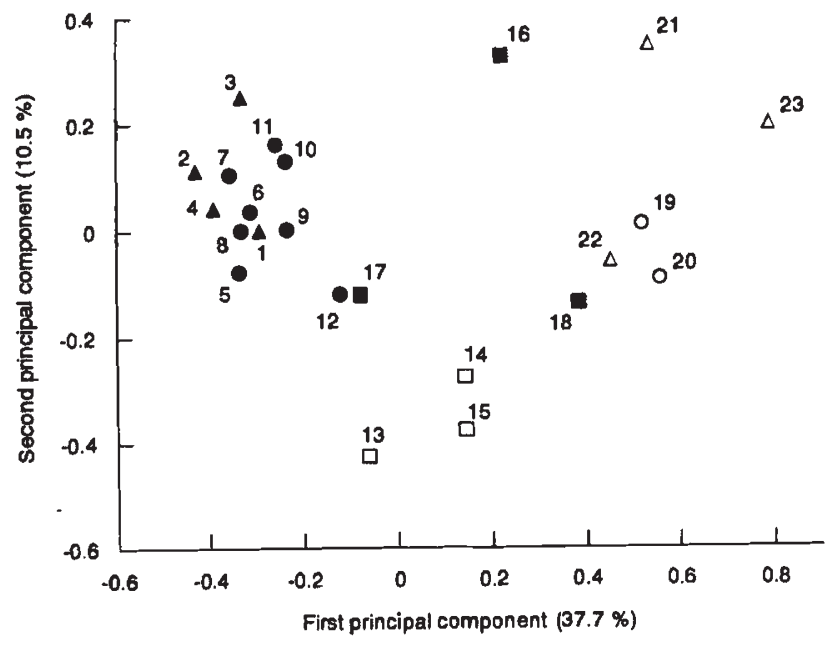

Fig. 3 Scatter diagram resulting from principal components analysis of angular-transformed allele frequencies from 23 populations of Fagus crenata. The two principal components explain 37.7 per cent and 10.5 per cent, respectively. Populations are given different symbols showing the locations in five geographical districts: $\Delta$, Hokkaido; •, Tohoku and Hokuriku; $\bullet$, Chugoku; $\square$, Kanto and Tokai; $\odot$, Shikoku; and $\Delta$, Kyushu. Numbers refer to population numbers in Table 3 . for long-lived woody plants were: $P_{1}=49.3$ per cent; $N_{\mathrm{a}}=1.76 ; N_{\mathrm{e}}=1.20$ and $H_{\mathrm{e}}=0.148$. These were lower than for $F$. crenata where $P_{1}=58.9$ per cent; $N_{\mathrm{a}}=2.66 ; N_{\mathrm{e}}=1.29$ and $H_{\mathrm{e}}=0.187$. By contrast, genetic differentiation among populations of $F$. crenata was less than one-half the average of longlived woody plants, as shown by $G_{\text {ST }}$ values for polymorphic loci, 0.038 vs. 0.084 , respectively. For total variation within species as indicated by $H_{\text {es }}$ (Hamrick \& Godt, 1989), equivalent to $H_{\mathrm{T}}$ over all loci in this study, $F$. crenata exhibited variation roughly similar to the average of long-lived woody plants $(0.194$ vs. $0.177)$.

In long-lived woody species, geographical range is the best indicator of genetic diversity (Hamrick et $a l ., 1992)$. In Japan, $F$. crenata forests are distributed within a regional range (Horikawa, 1972). Comparing the genetic diversity in $F$. crenata with that in long-lived woody plants also having regional ranges $\left(P_{1}=69.2\right.$ per cent; $N_{\mathrm{a}}=2.31 ; N_{\mathrm{e}}=1.26 ; H_{\mathrm{e}}=0.194$; $G_{\mathrm{ST}}=0.065$ and $H_{\mathrm{es}}=0.169$ ), genetic diversity in $F$. crenata was found to be generally similar for withinpopulation and within-species variation but lower for among-population variation. 
Additional characteristics influencing genetic diversity in plant species are the breeding systems and seed dispersal methods (Hamrick \& Godt, 1989; Hamrick et al., 1992). It is known that $F$ crenata outcrosses through wind-pollination. Beech nuts are dispersed by gravity and then scattered and hoarded by animals such as wood mice (Apodemus speciosus and $A$. argenteus; Miguchi, 1994) and Japanese nutcrackers (Nucifraga caryocatactes japonicus) and jays (Garrulus gladnarius pallidifrons; Watanabe, 1990). However, the extent of population differentiation in $F$. crenata is inconsistent with, and lower than, a typical wind-pollinated, outcrossing species (average $G_{\mathrm{ST}}=0.077$ ) or a typical species whose seed are dispersed by gravity (average $G_{\mathrm{ST}}=0.131$ ). Hamrick et al. (1992), however, did not summarize data for species with seed dispersal by caching. Although there are no data of $F$. crenata seed dispersal by birds, Johnson \& Adkisson (1985) described seed dispersal of $F$. grandifolia by blue jays (Cyanocitta cristata). They found that about 75 blue jays transported and cached approximately 100000 beech nuts over distances from a few tens of metres up to $4 \mathrm{~km}$ from a woodlot during September. In contrast, the dispersal distances of beech nuts by wood mice were relatively short, within $5 \mathrm{~m}$ for $F$ crenata (Miguchi, 1994) and 1-13 m for F. sylvatica (Jensen, 1985). As both pollen dispersal (Levin \& Kerster, 1974) and seed dispersal by rodents is often effective only over short distances, long-range seed dispersal by birds may be an important source of gene flow between scattered populations (Vander Wall, 1990). Therefore, the high rate of gene flow generated especially by bird dispersal of beech nuts has possibly contributed to the low differentiation in $F$. crenata. It is more likely, however, that the recent evolutionary history of $F$. crenata has contributed to this low differentiation.

The average number of migrants exchanged per generation $(\mathrm{Nm})$ was estimated to be 6.3. This parameter reflects historical gene flow rates that would vary from generation to generation. Although the estimates should be treated with caution (Slatkin \& Barton, 1989), when considering many other species, this estimate of $\mathrm{Nm}$ is rather high (Govindaraju, 1988). Theoretical studies have shown that a relatively low gene flow, $N m>1$, is sufficient to hamper population differentiation caused by genetic drift at neutral loci (Wright, 1931; Maruyama, 1970; Levin \& Kerster, 1974; Slatkin \& Maruyama, 1975). Therefore, for $F$ crenata with a relatively large population size, the high rate of gene flow within and between populations may have prevented the loss of variation and differentiation between populations.

\section{Geographical patterns of genetic diversity}

Genetic diversity in Fagus crenata mostly corresponds to the generalization of genetic diversity in long-lived woody plants (Hamrick \& Godt, 1989; Hamrick et al., 1992), i.e. long-lived woody plants have relatively high genetic diversity within species, but most of the genetic diversity is within populations with little existing among populations. There are, however, remarkable characteristics in the genetic diversity of $F$. crenata, i.e. although there was low differentiation among populations, geographical patterning of the variation was clearly observed. First, the within-population variation tend to be lower in the more north-eastern populations, as indicated by $H_{\mathrm{e}}$ and $N_{\mathrm{e}}$ values, despite the south-western Japan populations being small and isolated, whereas those in north-eastern Japan are large and widespread. This fact is inconsistent with the general tendency for more widespread populations to retain greater genetic diversity than more geographically restricted populations.

Secondly, population differentiation appears to have proceeded less in north-eastern Japan, as indicated by $D_{j}$ values. This fact was further confirmed by gene diversity analysis (Nei, 1973). Estimates of $G_{\text {ST }}$ values were made for each of the eight southwestern populations from the Chugoku, Shikoku and Kyushu districts and for the 12 north-eastern populations from the Hokkaido, Tohoku and Hokuriku districts. Population differentiation (mean $G_{S T}=$ $0.007 \pm 0.002$ ) in the north-eastern populations was less than one-quarter of that in the south-western populations $(0.031 \pm 0.013)$.

Thirdly, allele frequencies observed at eight loci showed significant clinal variation across the range of the species. Furthermore, this tendency was emphasized by the principal components analysis because the synthesized principal components resulted from the accumulated differences of frequencies for many alleles, most of which were the same alleles exhibiting the clinal variation. Indeed, the populations in the analysis tended to cluster according to their geographical locations. Noticeably, a high proportion (88.2 per cent) of the variance of the first principal component was explained by the geographical locations of the populations.

These characteristics are probably accounted for by the recent migration history of $F$. crenata. According to palynological studies (Tsukada, 1982a,b), multiple refugia were sparsely located only along coastal belts south of approximately $38^{\circ} \mathrm{N}$ latitude during the full-glacial period (25000-15000 years BP). Approximately 12000 years ago, Fagus forests

(C) The Genetical Society of Great Britain, Heredity, 78, 241-251. 
began to expand rapidly northwards and to higher altitudes from the coastal refugia. It is particularly worthwhile to consider the following three distributional shifts of Fagus forests: (i) in south-western Japan, Fagus populations moved to higher altitudes and were isolated by about 7000 years ago; (ii) in central and north-eastern Japan, Fagus populations were fully established in their present distribution by about 7000 years ago; (iii) the new Fagus populations in north-eastern Japan must have been founded by migrants from the northern populations of its glacial refugia (approximately $38^{\circ} \mathrm{N}$ latitude). Because Japanese Fagus comprises two species, $F$. crenata and $F$. japonica, Tsukada's hypothesis included both species. Nevertheless, the inference about the distribution shift on the Japan Sea side would be for $F$. crenata as $F$. japonica is generally restricted to the Pacific side (Horikawa, 1972).

The north-eastern populations of $F$. crenata obviously originated from the peripheral refugia north of the last glacial distribution. These peripheral refugia possibly maintained a lower diversity than the multiple refugia located on the more south-western coasts. In present populations of various tree species, the tendency has been found for marginal populations to maintain lower diversity than in central populations (Guries \& Ledig, 1982; Michaud et al., 1995). The distributional expansion allowed by climatic amelioration after the glacial maximum was probably accomplished by repeated founding events, presumably through dispersal by birds (Vander Wall, 1990). Consequently the variation in new populations founded with small population size may have further decreased because of genetic drift during the succeeding postglacial migration. When population size is reduced, the genetic variation is expected to decline because of genetic drift. The rate of decline depends on the effective population size (Wright, 1931; Nei et al., 1975). Such a distribution in the last glaciation and the following migration events could explain the result that variation within $F$ crenata populations declined in more north-eastern populations. In a study of Pinus contorta, the results of allozyme analysis clearly suggest that stochastic genetic drift in long-distance founding events during its postglacial spread resulted in the reduced allelic diversity in the populations founded toward the northern distribution limit (Wheeler \& Guries, 1982a,b; Cwynar \& MacDonald, 1987). Similar results have been reported for Picea abies where central European populations have consistently low genetic variability, most probably as an effect of severe population size reductions during the last glaciation (Lagercrantz \& Ryman, 1990).
Fagus crenata populations in south-western Japan, when compared with geographically restricted populations of long-lived woody plants, revealed relatively high within-population variation despite the small population size in the mountains. Therefore, even now, variation in the south-western populations may reflect the high variation presumably maintained in the multiple refugia or the descendent populations (Hiebert \& Hamrick, 1983; Niebling \& Conkle, 1990 ), i.e. because of genetic drift, the present populations may not have lost completely the variation within the ancestral populations.

If the process of population expansion in northeastern Japan had really happened, population differentiation may have proceeded between the newly established populations. Nevertheless, very limited differentiation was found among northeastern Japan's present populations, indicating that gene flow may have been so high that the population differentiation was prevented because of the relatively continuous range of $F$. crenata in north-eastern Japan. This has probably contributed to the low between-population differentiation of $F$. crenata at the species level. Alternatively, for populations in south-western Japan, isolated at least since early in the postglacial period, the interpopulational differentiation has been somewhat greater. Comps et al. (1990) also reported that genetic differentiation in Fagus sylvatica was greater in the Mediterranean region compared with that in the Continental region because the populations in the Mediterranean region had been spread out from several sources isolated from each other during glaciations.

Clinal variation of allele frequencies along latitude and/or longitude has been reported for several tree species (e.g. F. sylvatica (Leonardi \& Menozzi, 1995); Picea abies (Lagercrantz \& Ryman, 1990); Quercus petraea (Zanetto \& Kremer, 1995)). These authors have generally proposed that geographical variation patterns in allele frequencies resulted from postglacial migration and founding events. The geographical clines of $F$. crenata allele frequencies probably also reflect the distribution of refugia in the last glacial maximum, subsequent migration and founding events. Clines in allele frequencies can be produced both by unidirectional and successive founding events through migration and by fusion through migration from two refugia that have become differentiated during separation. The adaptive significance of allozymes along environmental gradients cannot be completely rejected, because even if the studied allozymes are neutral or nearly neutral, natural selection can indirectly affect allozymes if they are linked to genes on which selection 
is acting. Nevertheless, the effect of late-Quaternary evolutionary events on $F$. crenata may provide the most reasonable explanation for the geographical pattern of allozymes found in this study.

\section{Acknowledgements}

We thank N. Kuramoto and N. Tani for their help in collecting bud samples, and C. Tomaru for her assistance in the laboratory. We also thank $\mathrm{H}$. Yoshimaru for helpful discussion on the manuscript. This research was partly funded by a Grant-in-Aid (No. 01304017) for Cooperative Research from the Ministry of Education, Science, Sports and Culture, Japan.

\section{References}

BRown, A. H. D. 1979. Enzyme polymorphism in plant populations. Theor. Pop. Biol., 8, 184-201.

COMPS, B., THIÉBAut, B., PAUle, L., MERZEAU, D. AND LETOUZEY J. 1990. Allozymic variability in beechwoods (Fagus sylvatica L.) over central Europe: spatial differentiation among and within populations. Heredity, 65, 407-417.

CWYNAR, L. C. AND MACDONALD, G. M. 1987. Geographical variation of lodgepole pine in relation to population history. Am. Nat., 129, 463-469.

DAVIS, B. J. 1964. Disk electrophoresis - II: method and application to human serum protein. Ann. N.Y. Acad. Sci., 121, 404-427.

GotTlieb, L. D. 1981. Electrophoretic evidence and plant populations. Prog. Phytochem., 7, 1-46.

GOVINDARAJU, D. R. 1988. Relationship between dispersal ability and levels of gene flow in plants. Oikos, 52, 31-35.

GREGORIUS, H.-R. AND ROBERDS, J. H. 1986. Measurement of genetical differentiation among subpopulations. Theor. Appl. Genet., 71, 826-834.

GURIES, R. P. AND LEDIG, F. T. 1982. Genetic diversity and population structure in pitch pine (Pinus rigida Mill.). Evolution, 36, 387-402.

HAMRICK, J. L. AND GODT, M. J. w. 1989. Allozyme diversity in plant species. In: Brown, A. H. D., Clegg, M. T., Kahler, A. L. and Weir, B. S. (eds) Plant Population Genetics, Breeding and Genetic Resources, pp. 43-63. Sinauer Associates, Sunderland, MA.

HAMRICK, J. L., LINHART, Y. B. AND MITTON, J. B. 1979. Relationships between life history characteristics and electrophoretically detectable genetic variation in plants. Ann. Rev. Ecol. Syst., 10, 173-200.

HAMRICK, J. L., GODT, M. J. W. AND SHERMAN-BROYLERS, S. L. 1992. Factors influencing levels of genetic diversity in woody plant species. New Forests, 6, 95-124.

HIEBERT, R. D. AND HAMRICK, J. L. 1983. Patterns and levels of genetic variation in Great Basin bristlecone pine, Pinus longaeva. Evolution, 37, 302-310.
HORIKAWA, Y. 1972. Atlas of the Japanese Flora, an Introduction to Plant Sociology of East Asia. Gakken, Tokyo.

JENSEN, T. S. 1985. Seed-seed predator interactions of European beech, Fagus sylvatica and forest rodents, Clethrionomys glareolus and Apodemus flavicollis. Oikos, 44, 149-156.

JOHNSON, w. C. AND ADKISSON, C. s. 1985. Dispersal of beech nuts by blue jays in fragmented landscapes. Am. Midl. Nat., 113, 319-324.

KIMURA, M. AND CROW, J. F. 1964. The number of alleles that can be maintained in a finite population. Genetics, 49, 725-738.

LAGERCRANTZ, U. AND RYMAN, N. 1990. Genetic structure of Norway spruce (Picea abies): concordance of morphological and allozymic variation. Evolution, 44, 38-53.

LEONARDI, S. AND MENOZZI, P. 1995. Genetic variability of Fagus sylvatica L. in Italy: the role of postglacial recolonization. Heredity, 75, 35-44.

LEVIN, D. A. AND KERSTER, H. W. 1974. Gene flow in seed plants. In: Dobzhansky, T., Hecht, M. K. and Steere, W. C. (eds) Evolutionary Biology, vol, 7, pp. 139-220. Plenum Press, New York.

LI, C. C. AND HORVITZ, D. G. 1953. Some methods of estimating the inbreeding coefficient. Am. J. Hum. Genet., 5, 107-117.

LI, P. AND ADAMS, W. T. 1989. Range-wide patterns of allozyme variation in Douglas-fir (Pseudotsuga menziesii). Can. J. Forest Res., 19, 149-161.

MARUYAMA, T. 1970. On the rate of decrease of heterozygosity in circular stepping stone models of populations. Theor. Pop. Biol., 1, 101-119.

MICHAUD, H., TOUMI, L., LUMARET, R., LI, T. X., ROMANE, F. AND DI GIUSTO, F. 1995. Effect of geographical discontinuity on genetic variation in Quercus ilex L. (holm oak). Evidence from enzyme polymorphism. Heredity, 74, 590-606.

MIGUCHI, H. 1994. Role of wood mice on the regeneration of cool temperate forest. In: Proceeding of NAFRO, Niigata, Japan, August 20, 1994, pp. 115-121. Northeast Asia Forest Research Organization, Niigata University.

NEI, M. 1972. Genetic distance between populations. Am. Nat., 106, 283-292.

NE1, M. 1973. Analysis of gene diversity in subdivided populations. Proc. Natl. Acad. Sci. U.S.A., 70, 3321-3323.

NEI, M. 1977. $F$-statistics and analysis of gene diversity in subdivided populations. Ann. Hum. Genet., 41, 225-233.

NEI, M. 1978. Estimation of average heterozygosity and genetic distance from a small number of individuals. Genetics, 89, 583-590.

NEI, M. AND CHESSER, R. K. 1983. Estimation of fixation indices and gene diversities. Ann. Hum. Genet., 47, 253-259.

NEI, M. AND ROYCHOUdHury, A. K. 1974. Sampling variances of heterozygosity and genetic distance. Genetics, 76, 379-390. 
Nel, M., MARUYama, T. AND ChakraborTy, R. 1975. The bottleneck effect and genetic variability in populations. Evolution, 29, 1-10.

NIEBLING, C. R. AND CONKLE, M. T. 1990. Diversity of Washoe pine and comparisons with allozymes of ponderosa pine races. Can. J. Forest Res., 20, 298-308.

ORNSTEIN, L. 1964. Disk electrophoresis - I: background and theory. Ann. N.Y. Acad. Sci., 121, 321-349.

QUenouille, M. H. 1952. Associated Measurements. Academic Press, New York.

SAS INSTITUTE 1985. SAS User's Guide: Statistics, Version 5th edn. SAS Institute, Cary, NC.

SLATKIN, M. AND BARTON, N. H. 1989. A comparison of three indirect methods of estimating average levels of gene flow. Evolution, 43, 1349-1368.

SLATK1N, M. AND MARUYAMA, T. 1975. The influence of gene flow on genetic distance. Am. Nat., 109, 597-601.

TAKAHASHI, M., TSUMURA, Y., NAKAMURA, T., UCHIDA, K. AND OHBA, K. 1994. Allozyme variation of Fagus crenata in northeastern Japan. Can. J. Forest Res., 24, 1071-1074.

THE ENVIRONMENT AGENCY 1988. The Third National Survey on the Natural Environment: Report on Vegetation Survey (national level). Asia Air Survey, Tokyo (in Japanese).

TSUKADA, M. 1980. The history of Japanese cedar: the last 15000 years. Kagaku (Science), 50, 538-546 (in Japanese).

TSUKADA, M. 1982a. Late-Quaternary development of the
Fagus forest in the Japanese archipelago. Jap. J. Ecol., 32, 113-118.

TSUKADA, M. 1982b. Late-Quaternary shift of Fagus distribution. Bot. Mag. Tokyo, 95, 203-217.

TSUMURA, Y. AND OHBA, K. 1993. Genetic structure of geographical marginal populations of Cryptomeria japonica. Can. J. Forest Res., 23, 859-863.

vander wall, s. B. 1990. Food Hoarding in Animals. The University of Chicago Press, Chicago.

WATANABE, s. 1990. Japanese beech (Fagus crenata): its characteristics and distribution. Nature in Hokkaido, 29, 1-6 (in Japanese).

WHEElER, N. C. AND GURIES, R. P. 1982a. Population structure, genic diversity and morphological variation in Pinus contorta Dougl. Can. J. Forest Res., 12, 595-606.

WHEELER, N. C. AND GURIES, R. P. 1982b. Biogeography of lodgepole pine. Can. J. Bot., 60, 1805-1814.

WORKMAN, P. L. AND NISWANDER, J. D. 1970. Population studies on southwestern Indian tribes. II. Local genetic differentiation in the Papago. Am. J. Hum. Genet., 22, 24-49.

WRIGHT, s. 1931. Evolution in Mendelian populations. Genetics, 16, 97-159.

WRIGHT, s. 1965. The interpretation of population structure by F-statistics with special regard to systems of mating. Evolution, 19, 395-420.

ZANETTO, A. AND KREMER, A. 1995. Geographical structure of gene diversity in Quercus petraea (Matt.) Liebl. I. Monolocus patterns of variation. Heredity, 75, 506-517. 